\title{
CYKL KONIUNKTURALNY GOSPODARKI POLSKI W LATACH 1996-2017
}

\author{
Bartosz Pawęta \\ Wydział Ekonomiczno-Socjologiczny \\ Uniwersytet Łódzki
}

\section{Streszczenie}

Fluktuacje gospodarcze, ich analiza i próba zrozumienia przyczyn od stuleci fascynują ekonomistów, niezależnie od tego, jaki nurt ekonomii reprezentują. Pomimo różnego rodzaju podejść naukowych, ludzie zawsze wykazywali chęć zrozumienia prawidłowości rządzących cykliczną naturą gospodarki, w tym także kryzysami ekonomicznymi. W niniejszej pracy podjęta została próba porównania charakterystyki morfologicznej cykli koniunkturalnych w Polsce przed i po kryzysie finansowym z roku 2008. Zweryfikowana została także spójność cech morfologicznych tychże cykli z teoretycznymi modelami cyklu klasycznego oraz współczesnego.

Wyniki jasno wskazują, że w badanym okresie gospodarka Polski nie znalazła się w recesji, lecz jej wzrost jest znacznie mniej dynamiczny niż przed kryzysem. Ponieważ prawie wszystkie badane cykle trwały około 3-4 lata, a ich charakterystyka morfologiczna, uległa przemianom i częściowo spełniona jest charakterystyka cyklu współczesnego, należy oczekiwać, że kolejne cykle w coraz większym stopniu będą pokrywały się z charakterystyką cyklu współczesnego.

Znaczenie niniejszej pracy jest o tyle ważne, iż jasno pokazuje ona, że cykliczna natura polskiej gospodarki zmieniła się na przestrzeni badanego okresu w zakresie amplitud jej cykli. Otrzymane rezultaty mogą okazać się użyteczne dla badaczy chcących przeprowadzić analogiczne badanie innych agregatów ekonomicznych, jak i wszystkich tych, w których interesie jest projekcja koniunktury gospodarczej.

Słowa kluczowe: cykl koniunkturalny, morfologia cykli, kryzys finansowy.

JEL Class: F44. 


\section{WPROWADZENIE}

Po kryzysie finansowym lat 2007-2008 powszechnie mówiło się o tym, że świat wkroczył w nową, nieznaną do tej pory, erę turbulencji [Kotler i Caslione 2009]. Istotne wydaje się więc zweryfikowanie, czy cykle koniunkturalne przebiegają tak jak przed kryzysem, czy też nie. Jest to kluczowa informacja z punktu widzenia projekcji dalszych zachowań gospodarki. Jeśli bowiem okaże się, że gospodarka nadal podąża dobrze znanym przez ekonomistów i finansistów torem, można wnioskować, że narzędzia i założenia dotyczące jej zachowań są nadal aktualne. Jeśli jednak nastąpiły zmiany w stosunku do lat przedkryzysowych, konieczna będzie rewizja stosowanej metodologii oraz założeń.

Jak zostanie wykazane, budowa cykli koniunkturalnych zmienia się w czasie. Na tej podstawie można podzielić cykle na dwie grupy: klasyczne i współczesne. Celem tego opracowania jest więc analiza cykli koniunkturalnych gospodarki polskiej w okresie 1996-2017 i sprawdzenie, czy odpowiadają one któremuś z powyższych modeli teoretycznych.

W pierwszej części pracy przedstawione zostaną główne teorie cykli koniunkturalnych. Jest to kluczowe dla zrozumienia cyklicznej natury gospodarki, a także wskazują metody jej analizy. Następnie przedstawiony zostanie koncept morfologii cykli koniunkturalnych. Konieczne jest bowiem używanie i zrozumienie specyficznych dla cykli pojęć i definicji. Dopiero wtedy można przystąpić do analizy cykli. Sama analiza przedstawiona w tej pracy stanowi niejako punkt startu dla dalszych prac badawczych. Choć zastosowane są relatywnie proste instrumenty badawcze, jasno pokazują one, jaki przebieg miały cykle koniunkturalne przed i po 2008 roku oraz jak zmiany te mogą być badane w innych obszarach.

\section{TŁO TEORETYCZNE}

Powodami, dla których w niniejszej pracy prezentowane są teorie cykli koniunkturalnych są:

1) cykle koniunkturalne to złożone, a jednocześnie bardzo ważne, zagadnienie ekonomiczne,

2) zjawisko cykli było przedmiotem badań wielu ekonomistów reprezentujących różne szkoły ekonomiczne, jednakże nadal nie zostało ono w pełni wyjaśnione,

3) przedstawione teorie wyjaśniają jak i jakie agregaty ekonomiczne można badać na potrzeby analizy cyklicznej natury gospodarki.

Przyjmuje się, że fakt występowania cykli w gospodarce został po raz pierwszy zaobserwowany około 1860 roku przez francuskiego ekonomistę 
Clementa Juglara [Marczak i Piech 2008: 2-3]. Jednakże w owym okresie, z uwagi na dominację ekonomistów reprezentujących szkołę klasyczną (na czele J.B. Say), panowało przekonanie, że fluktuacje te mają charakter incydentalny, a ich badanie zbyteczne [Say (w:) Marczak i Piech 2008].

W tym samym okresie powstawały także alternatywne teorie. Niektóre starały się wyjaśnić zjawisko cykli poprzez matematykę, inne przez psychologię, a niektóre sięgały nawet do astronomii [Malthus, St. Jevons, Prescott (w:) Marczak i Piech 2008: 3-4]. W niniejszej pracy skupimy się jednak na najważniejszych teoriach dotyczących przyczyn powstawania cykli koniunkturalnych.

Teorie te podzielić można na dwie grupy: endogeniczne i egzogeniczne.

Koncepty endogeniczne wiążą się ze szkołą keynesowską, choć sam J.M. Keynes skupiał się raczej na poszukiwaniu możliwości łagodzenia negatywnych skutków kryzysów ekonomicznych, a nie na samych cyklach [Jędruchniewicz 2012: 40]. Niemniej, opracowane teorie upatrywały przyczyn powstawania fluktuacji pośród czynników wewnętrznych, to jest występujących wewnątrz danego systemu ekonomicznego.

Szkoła keynesowska dzieli czynniki wewnętrzne na dwie grupy zmiennych: zmiennych zależnych oraz zmiennych niezależnych. Zaproponowany model przedstawia rys. 1 .

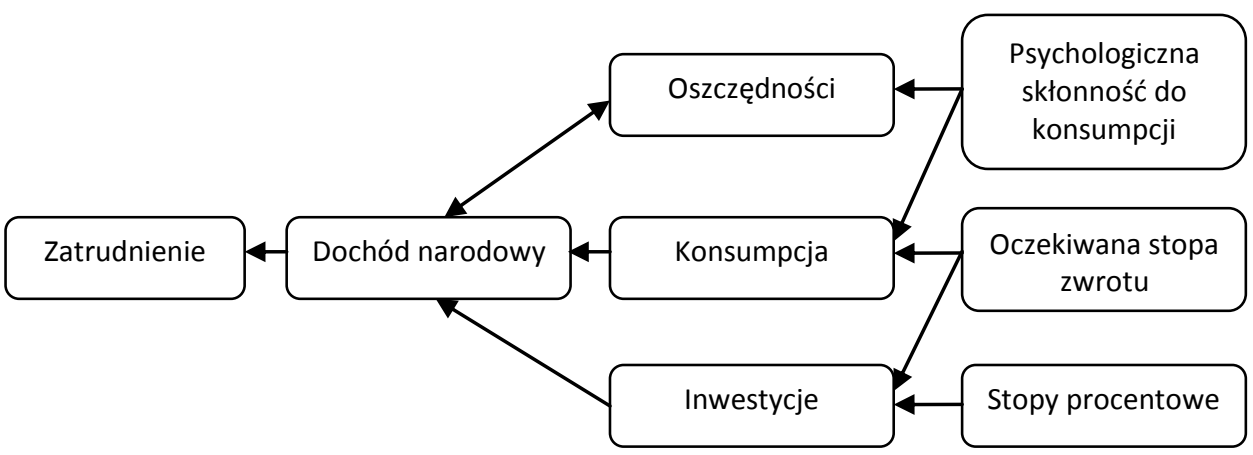

Zmienne zależne

Zmienne niezależne

Rysunek 1. Zmienne w modelu Keynes'a

Źródło: Górski i Sierpiński [1979: 324].

W modelu tym kluczowym elementem jest dochód narodowy, na który bezpośrednio wpływa poziom oszczędności, konsumpcji oraz inwestycji, które to z kolei podlegają wpływowi psychologicznej skłonności do konsumpcji, oczekiwań co do stopy zwrotu z inwestycji oraz wysokości stóp procentowych. Cen- 
tralnym elementem wzrostu gospodarczego jest natomiast zależność pomiędzy dochodem narodowym a inwestycjami. Poziom inwestycji zależy od wysokości stóp procentowych oraz ducha przedsiębiorczości, a ponieważ rzadko kiedy poziom inwestycji jest równy poziomowi oszczędności, w systemie występują fluktuacje dochodu narodowego. Dalsze badania wprowadzające koncept mnożnika-akceleratora dowodziły, że rodzaje fluktuacji mogą się różnić [Hicks (w:) Jakimowicz 2005], jednakże każdy kolejny szczyt dochodu narodowego mierzonego poprzez Produkt Krajowy Brutto (PKB) jest osiągany na wyższym poziomie niż szczyt poprzedni [Smithies 1966].

Model opracowany przez Keynesa przedstawia następujący przebieg cyklu koniunkturalnego: Inwestycje na rynku rozpoczynają się wtedy, gdy na rynku panuje przekonanie, że stopy zwrotu z inwestycji będą rosły [Jakimowicz 2005: 42-45]. Przez pewien okres podmioty (przedsiębiorstwa) działające na rynku ignorują fakt wzrostu kosztów produkcji, a także stóp procentowych. W tym samym czasie zwiększają volumen produkcji, poziom dochodu i zatrudnienia. W pewnym momencie wysokie ceny zasobów (a nawet brak niektórych $\mathrm{z}$ nich) rodzą obawy o możliwość dalszego wzrostu. Kiedy pojawia się poczucie rozczarowania, spada poziom dochodu oraz oczekiwania co do przyszłych stóp zwrotu. W rezultacie spadają także notowania akcji oraz poziom konsumpcji. Sytuacja taka utrzymuje się do momentu, gdy pewnych dóbr na rynku zaczyna brakować, a to $\mathrm{z}$ kolei rodzi kolejny wzrost oczekiwań dotyczących możliwości wzrostu stóp zwrotu z inwestycji, co inicjuje rozpoczęcie nowego cyklu koniunkturalnego.

W przeciwieństwie do konceptów endogenicznych przedstawionych powyżej, koncepty egzogeniczne upatrują przyczyn fluktuacji pośród czynników zewnętrznych, to jest występujących poza samym systemem ekonomicznym [Muth, Ricardo (w:) Barczyk i Kowalczyk 1993]. Trzeba odnotować, że większość tego rodzaju teorii wyrosła na kanwie niedoskonałości modeli Keynes'a, w szczególności (1) niemożliwości wprowadzenia do modelu przyszłych oczekiwań [Kalecki 1979: 272] oraz (2) brak wytłumaczenia przyczyn jednoczesnego występowania wysokiej inflacji i wysokiego poziomu bezrobocia [Barczyk i Kowalczyk 1993: 45]. Zjawiska te znajdują wyjaśnienie pośród teorii monetarystów, którzy wiążą fluktuacje ekonomiczne z rynkami finansowymi. Kluczowym elementem jest tutaj wpływ polityki monetarnej i fiskalnej, jako że podaż pieniądza rodzi dysproporcje pomiędzy poziomami podaży i popytu na rynku [Barczyk 2006: 65-68]. W okresie wzrostu gospodarczego, kiedy stopy procentowe banku centralnego są niższe niż efektywne stopy rynkowe (czyli takie, jakie obowiązywałyby, gdyby bank centralny nie istniał), podmioty rynkowe zaciągają kredyty, nawet jeśli nie do końca są one im potrzebne. Powoduje to nadpodaż dóbr, które muszą przecież zostać sprzedane, by przedsiębiorstwa mogły spłacać raty kredytu. Skutkuje to obniżeniem cen, spadkiem dochodu, a także ryzykiem niemożliwości regulowania zobowiązań handlowych i kredytowych. 
Niektórzy słynni ekonomiści reprezentujący poglądy egzogeniczne [np. Friedman i Schwarz 1963] twierdzą, że fluktuacje w gospodarce są zjawiskiem pozytywnym, ponieważ są one skutkiem optymalnych decyzji podejmowanych przez podmioty działające na rynku [Marczak i Piech 2008: 5-11]. Co więcej, pozwalają one na eliminację z rynku zbyt mocno zadłużonych podmiotów. Rolą państwa w systemie powinno być natomiast jedynie łagodzenie negatywnych skutków spowolnienia gospodarczego poprzez ograniczanie zbyt gwałtownego wzrostu gospodarczego (zbyt gwałtowna ekspansja może skutkować gwałtowną recesją). Wszelkie reakcje ex post na spowolnienie gospodarcze występujące po pęknięciu bańki inwestycyjnej w danym sektorze gospodarki, rodzą kolejne bańki inwestycyjne w innym sektorze [Białek 2008].

Poza czynnikami monetarnymi, istnieją także inne czynniki egzogeniczne. Wśród nich są na przykład zmiany klimatyczne, wojny, rewolucje technologiczne czy czynniki polityczne [Piech 2003: 59-82]. Dla potrzeb niniejszej pracy istotne jest podkreślenie złożoności omawianego zagadnienia oraz zaznaczenia, że nie istnieje jedna uniwersalna teoria wyjaśniająca wszystkie zagadnienia cykli koniunkturalnych.

\section{DEFINICJE I RODZAJE CYKLI KONIUNKTURALNYCH}

Aby możliwe było przeprowadzenie analizy cykli koniunkturalnych, konieczne jest zdefiniowanie pewnych pojęć. Pozwoli to zrozumieć wyniki badań zaprezentowanych w tej pracy, jak i innych analiz dotyczących tego zagadnienia.

Zachowanie w czasie badanego agregatu makroekonomicznego może przybierać następujące formy [Rekowski 1997: 18-19]:

a) trend, a właściwie linia trendu, która wskazuje kierunek zmian wartości w dłuższej perspektywie. Trend może być pozytywny (wzrost gospodarczy), negatywny (spowolnienie) lub neutralny (stabilizacja);

b) fluktuacje okresowe, które zwykle mierzone są w dniach, tygodniach, ewentualnie miesiącach. Są to zwykle krótkotrwałe wahania koniunktury spowodowane specyficznymi zachowaniami społeczeństwa, ilością dni pracujących w danym okresie, czynnikami klimatycznymi lub innymi sezonowymi;

c) fluktuacje losowe spowodowane bliżej nieokreślonymi czynnikami, jednak niezależnymi od procesów zachodzących w danym systemie ekonomicznym;

d) fluktuacje gospodarcze, które są oscylacjami danego agregatu ekonomicznego wokół linii trendu. Oscylacje te mogą mieć różną długość (krótki oraz średni termin trwania). Zawsze jednak wywołane są poprzez czynniki ekonomiczne. 
Cykle ekonomiczne są specyficzną odmianą fluktuacji gospodarczych. Jednakże nie wszystkie fluktuacje gospodarcze mogą być uznane za cykle, ponieważ cykle to występująca naprzemiennie pozytywna i negatywna zmiana danego procesu. Warto w tym momencie przedstawić trzy definicje cykli ekonomicznych, które oparte są na metodologii używanej do analizy serii danych (w tym wypadku agregatów ekonomicznych):

a) cykl wzrostowy [Mintz 1972: 41]. Cykl wzrostowy powstaje dzięki wyznaczeniu linii trendu i wyodrębnieniu dwóch okresów danego cyklu: o relatywnie wysokim tempie wzrostu oraz o relatywnie niskim tempie wzrostu;

b) cykl odchyleń [Mintz 1972: 41]. Cykl odchyleń powstaje poprzez zaprezentowanie linii trendu jako poziomej osi układu współrzędnych, wówczas wartości osi pionowej wskazują odchylenie danych od linii trendu;

c) cykl kroczący [Friedman i Schwartz 1963: 32-78]. Cykl kroczący otrzymuje się poprzez obliczenie tempa zmian wartości danego agregatu ekonomicznego (np. Produkt Krajowy Brutto osiągnięty w danym kwartale/PKB w kwartale poprzednim). Popularną metodą jest też mierzenie tempa zmian danej zmiennej w danym okresie wobec analogicznego okresu roku poprzedniego. Cykl kroczący jest więc nową serią danych otrzymanych na podstawie wartości danego agregatu ekonomicznego.

Zaletą cyklu kroczącego jest to, że nie wymaga on wyznaczania linii trendu, co jest konieczne przy analizie cyklu wzrostowego i cyklu odchyleń. W niniejszej pracy przyjmujemy, że cyklem ekonomicznym określamy cykl kroczący serii danych Produktu Krajowego Brutto.

W literaturze przedmiotu spotyka się też inny popularny podział na dwa rodzaje cykli koniunkturalnych [Barczyk i Kowalczyk 1993: 28].

1) cykle klasyczne, które występowały przed II wojną światową,

2) cykle współczesne, obserwowane po II wojnie światowej.

Ich cechy charakterystyczne zostały przedstawia tab. 1

Tabela 1 wskazuje, że główną różnicą pomiędzy cyklami jest czas ich trwania. Cykle współczesne są bowiem krótsze, ze strefami zwrotu zamiast wyraźnie zaznaczonymi punktami zwrotu, oraz dwiema fazami zamiast wyraźnymi czterema. Ich amplituda jest natomiast pozytywna i rosnąca, a nie bliska zeru, jak ma to miejsce w cyklach klasycznych. Znacznie trudniej też zidentyfikować bezpośrednie przyczyny ich zachowania, gdyż składa się na to znaczna ilość złożonych relacji wielu zmiennych.

Można jednak wskazać trzy często występujące przyczyny:

1) zmiany strukturalne - prywatyzacja w byłych gospodarkach centralnie planowanych wraz z dynamicznym wzrostem przedsiębiorstw skutkuje rosnącą amplitudą cykli; 
2) antycykliczna polityka rządów sprawia, że cykle są krótsze, punkty zwrotne mniej wyraźne, a amplituda rosnąca. Władze starają się bowiem utrzymywać stały wzrost gospodarczy i zapobiegać kryzysom ekonomicznym;

3) internacjonalizacja procesów gospodarczych - przepływ informacji, kapitału, ludzi, dóbr i usług jest łatwy jak nigdy wcześniej, co sprawia, że znaczna liczba zmiennych o charakterze globalnym ma wpływ na gospodarkę na poziomie narodowym.

Tabela 1. Porównanie teoretycznych charakterystyk cyklu klasycznego i współczesnego

\begin{tabular}{|c|c|c|}
\hline Morfologia & Cykl klasyczny & Cykl współczesny \\
\hline Ilość faz & 4 & 2 \\
\hline Punkty zwrotne & Ostre i wyraźne & Strefy zwrotne \\
\hline $\begin{array}{l}\text { Długość } \\
\text { - faza wzrostowa }\end{array}$ & $4-6$ lat & 2-3 lata \\
\hline - faza spadkowa & $4-6$ lat & $1,5-2$ lata \\
\hline - cały cykl & $8-12$ lat & $3,5-5$ lat \\
\hline Częstotliwość & Niska & Wysoka \\
\hline $\begin{array}{l}\text { Amplituda: } \\
\text { - faz }\end{array}$ & - podobne amplitudy & $\begin{array}{l}\text { - wyższa amplituda fazy wzro- } \\
\text { stowej niż spadkowej }\end{array}$ \\
\hline - cyklu & - amplituda bliska zeru & - amplituda rosnąca \\
\hline Intensywność & Wysoka & Niska \\
\hline Symetryczność & Asymetryczność & Asymetryczność \\
\hline \multicolumn{3}{|l|}{ Struktura } \\
\hline Przesunięcie w czasie & $\begin{array}{l}\text { Znaczne przesunięcie w czasie } \\
\text { między punktami zwrotnymi } \\
\text { agregatów ekonomicznych }\end{array}$ & $\begin{array}{l}\text { Nieznaczne przesunięcie } \\
\text { w czasie między punktami } \\
\text { zwrotnymi agregatów ekono- } \\
\text { micznych }\end{array}$ \\
\hline Przyczyna i skutki fluktuacji & $\begin{array}{l}\text { Proste zależności, niewielka } \\
\text { ilość zmiennych }\end{array}$ & $\begin{array}{l}\text { Skomplikowane zależności, } \\
\text { wiele zmiennych }\end{array}$ \\
\hline
\end{tabular}

Źródło: opracowanie własne w oparciu o: Barczyk i Kowalczyk [1993: 29].

\section{METODOLOGIA}

Identyfikacja cykli w serii danych wymaga zastosowania właściwej metodologii. W niniejszej pracy zastosowana jest metodologia Bry-Boschan [Massmann $\mathrm{i}$ in. 2003: 102-103], która wskazuje następujące:

a) górny punkt danego cyklu występuje w kwartale t, jeśli wartości cyklu w kwartale poprzedzającym oraz następującym po t, są niższe niż w kwartale $t$, 
b) cykl osiąga dolny punkt zwrotny, jeżeli wartości cyklu w kwartale poprzedzającym oraz następującym po t, są wyższe niż w kwartale $t$,

c) każda faza cyklu musi trwać co najmniej dwa kwartały,

d) długość cyklu nie może być mniejsza niż pięć kwartałów,

e) gdy dany cykl się kończy, rozpoczyna się następny.

Konieczne jest także przedstawienie terminologii, która umożliwi dyskusję na temat cech morfologicznych cykli koniunkturalnych.

Punkty zwrotne - to najważniejsze punkty cyklu. Wskazują gdzie zaczynają się i kończą poszczególne fazy cyklu, a także gdzie dany cykl zaczyna się i kończy. Cykl trwa bowiem pomiędzy dwoma punktami zwrotnymi tego samego rodzaju (tj. górnymi bądź dolnymi). Górne punkty zwrotne określa się także mianem 'maksimum lokalnego' lub 'szczytem cyklu'. Dolne punkty zwrotne określa się jako 'minimum lokalne' lub 'dno cyklu'.

Fazy - na podstawie definicji punktów zwrotnych można powiedzieć, że faza to okres pomiędzy dwoma punktami zwrotnymi przeciwnego rodzaju. Podstawowy podział faz wyróżnia fazę wzrostową (od dna do szczytu cyklu) oraz fazę spadkową (od szczytu do dna cyklu). Te dwie fazy mogą także być podzielone na pod-fazy: ekspansja, dobrobyt, spowolnienie, kontrakcja [Barczyk 2006: 140].

Długość - czas trwania fazy to jej długość. Analogicznie długość cyklu to czas jego trwania, równy sumie długości jego faz.

Częstotliwość - to odwrotność długości cyklu. Określa ile cykli przypada na daną jednostkę czasu.

Amplituda - możliwe jest określenie amplitudy pojedynczej fazy jak i cyklu. Amplituda fazy to wartość bezwzględna różnicy pomiędzy wartościami, jakie przyjmuje cykl na początku i końcu fazy. Amplituda cyklu jest równa różnicy pomiędzy amplitudami jego faz. Można wyróżnić trzy rodzaje amplitud: stałe, tłumione, eksplozywne.

Intensywność - równa jest odchyleniu standardowemu serii danych. Mierzy siłę wzrostu (spadku) fazy lub cyklu.

Symetria/asymetria - cykl może być symetryczny względem amplitud jego faz. Jeśli amplitudy są równe, amplituda cyklu jest równa zero. Cykle symetryczne względem długości faz, jeśli długość faz jest sobie równa.

W niniejszej pracy opieramy na danych OECD. Ze względu na dostępność wiarygodnych danych, badany okres trwa od pierwszego kwartału 1996 do trzeciego kwartału 2017. Analizowana seria danych to kwartalne zmiany wartości realnego Produktu Krajowego Brutto [dane pobrane zostały 5.12.2017]. Na podstawie opisanych wyżej danych został skonstruowany cykl odchyleń przy zastosowaniu filtra Hodrick-Prescott'a. 


\section{WYNIKI BADAŃ}

Jak wskazano w opisanych wcześniej teoriach, wielu ekonomistów zgadzało się co do użycia PKB jako głównego wskaźnika w badaniu cykli ekonomicznych. Dlatego też w niniejszej pracy uwaga zostanie skupiona na badaniu tylko tej zmiennej. Co więcej, praca ta ma na celu stanowić punkt odniesienia dla dalszych podobnych badań z zastosowaniem innych agregatów ekonomicznych.

Analizie poddane zostaną więc cykle kroczące Produktu Krajowego Brutto kwartał do kwartału roku poprzedniego. Graficzny ich przebieg prezentuje wykres 1. Jak łatwo zauważyć, w badanym okresie wystąpiło sześć pełnych cykli.

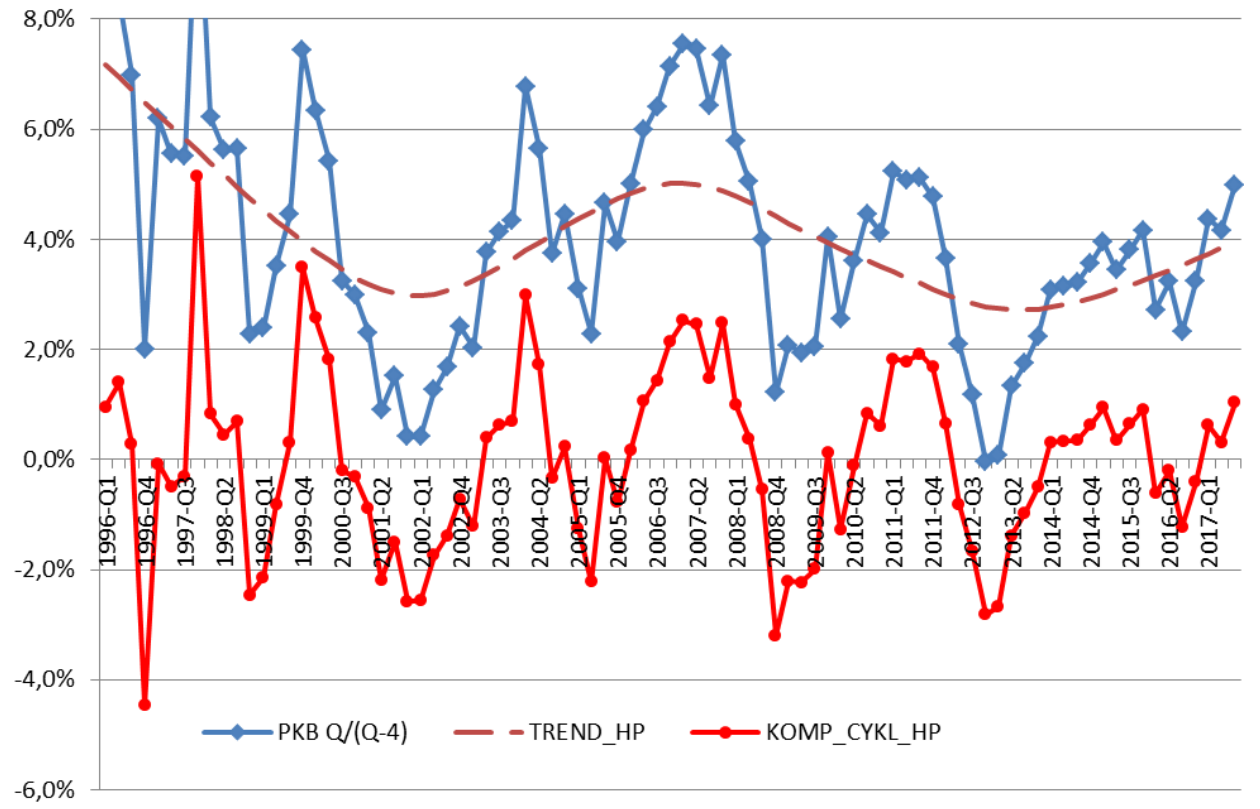

Wykres 1. Cykle koniunkturalne w Polsce przed i po kryzysie finansowym 2008 roku

Źródło: opracowanie własne.

Cykl 1 rozpoczął się w 1996Q4 (czwarty kwartał 1996 roku) i trwał 8 kwartałów. Był to pierwszy cykl gospodarczy Polski, który po przemianach ustrojowych roku 1989 wykazywał względną stabilność. Cykl 2 zaczął się w 1998Q4 i trwał 13 kwartałów. Był to cykl, który rozpoczął się po tzw. kryzysie azjatyckim i rosyjskim. Cykl 3 rozpoczął się w 2002Q2 i trwał również 13 kwartałów. Był to cykl, który zapoczątkował ożywienie po globalnym spowolnieniu związanym z kryzysem spółek internetowych (ang. Dotcom crash). 
Cykl 4 zaczął się w 2005Q2 i trwając 14 kwartałów zakończył się w 2008Q4. To w trakcie trwania tego cyklu doszło do (jednego z największych w historii) kryzysu finansowego. Cykl 5 zaczynający się od 2008Q4 i trwający 16 kwartałów można uznać za pierwszy pokryzysowy cykl gospodarczy. Ostatni pełny cykl w badanym okresie to Cykl 6 trwający od 2012Q4 przez 15 kwartałów.

Na szczególną uwagę zasługuje fakt, że w badanym okresie Polska nigdy nie znalazła się w recesji, bowiem wartości tempa wzrostu PKB nigdy nie znalazły się poniżej linii ZERO. Jednakże nachylenie linii trendu widocznej na wykresie jest negatywne, co oznacza, że tempo rozwoju gospodarki Polski jest coraz wolniejsze.

Ta obserwacja zgadza się z wynikami badania, które przeprowadzili K. Beck i M. Grodzki [2014], którzy badali zbieżność i synchronizację cykli na obszarze Unii Europejskiej. Zwalniające tempo wzrostu gospodarczego jest następstwem doganiania przez Polskę bardziej rozwiniętych gospodarek krajów UE.

Kolejnym zagadnieniem jest to, czy cykle gospodarcze Polski wpisują się w teoretyczne modele cyklu klasycznego bądź współczesnego oraz to, czy/jak ich morfologia zmieniła się po kryzysie 2008 roku.

Charakterystykę cyklu klasycznego i współczesnego prezentuje tab. 1, którą można porównać $\mathrm{z}$ wynikami przeprowadzonej analizy, zawartymi w tab. 2.

Wyniki wskazują, że Cykl 1 spełnia parametry cyklu klasycznego (za wyjątkiem długości). Ma zarysowane 4 fazy, ostre punkty zwrotne oraz amplitudę bliską zeru. Wszystkie kolejne cykle mają widoczne 2 fazy i, co istotne, wyraźnie zaznaczone dolne punkty zwrotne. Pozwala to dość jednoznacznie stwierdzić, kiedy zaczyna się kolejny cykl gospodarczy. Górne punkty zwrotne w cyklach 1-3 są wyraźnie zarysowane, natomiast począwszy od szczytu tempa wzrostu przypadającego na kryzys gospodarczy, górne punkty zwrotne są bardziej rozmyte i przypominają strefy zwrotne. Amplitudy cykli różnią się dość znacznie i w badanym okresie nie są jednorodne. Jak zostało już zaznaczone, amplituda Cyklu 1, będąca bliską zeru, spełnia parametry cyklu klasycznego. Z kolei Cykl 2 (po kryzysie azjatyckim i rosyjskim) oraz Cykl 4 (kryzysowy) i Cyk 5 (pokryzysowy) mają amplitudy ujemne. Sugeruje to, że gospodarka Polski potrzebuje całego pełnego cyklu po kryzysie gospodarczym, by jej cykl koniunkturalny wszedł w okres, w którym amplituda cykli jest dodatnia i spełnia parametry cyklu współczesnego.

Długość cykli wskazuje jednak, że każdy z nich (za wyjątkiem Cyklu 1) trwał około 4 lat. Sugeruje to zbieżność z długością cyklu współczesnego. Otrzymane wyniki pokrywają się także $\mathrm{z}$ innymi badaniami przedmiotu [Skrzypczyńska 2012: 11]. Podsumowanie analizy prezentuje tab. 3. 
Tabela 2. Wyniki analizy morfologicznej cykli koniunkturalnych w Polsce

\begin{tabular}{|l|c|c|c|c|c|c|c|}
\hline & Cykl 1 & Cykl 2 & Cykl 3 & Cykl 4 & Cykl 5 & Cykl 6 & Cykl 7 \\
\hline Początek & $1996-Q 4$ & $1998-Q 4$ & $2002-Q 1$ & $2005-Q 2$ & $2008-Q 4$ & $2012-Q 4$ & $2016-Q 3$ \\
\hline Koniec & $1998-Q 4$ & $2002-Q 1$ & $2005-Q 2$ & $2008-Q 4$ & $2012-Q 4$ & $2016-Q 3$ & $?$ \\
\hline $\begin{array}{l}\text { Punkty zwrotne } \\
\text { Dolny }\end{array}$ & $1996-\mathrm{Q} 4$ & $1998-\mathrm{Q} 4$ & $2002-\mathrm{Q} 1$ & $2005-\mathrm{Q} 2$ & $2008-\mathrm{Q} 4$ & $2012-\mathrm{Q} 4$ & $2016-\mathrm{Q} 3$ \\
\hline Górny & $1997-\mathrm{Q} 4$ & $1999-\mathrm{Q} 4$ & $2004-\mathrm{Q} 1$ & $2007-\mathrm{Q} 1$ & $2011-\mathrm{Q} 3$ & $2015-\mathrm{Q} 4$ & $?$ \\
\hline $\begin{array}{l}\text { Długość } \\
\text { Faza wzrostowa }\end{array}$ & & & & & & & \\
\hline Faza spadkowa & 4 & 4 & 8 & 7 & 11 & 12 & $?$ \\
\hline Cykl & 8 & 13 & 13 & 14 & 16 & 15 & $?$ \\
\hline Amplituda & & & & & & & \\
Faza wzrostowa & 8,75 & 5,17 & 6,36 & 5,26 & 3,90 & 4,20 & $?$ \\
\hline Faza spadkowa & $-8,49$ & $-7,02$ & $-4,49$ & $-6,32$ & $-5,16$ & $-1,85$ & $?$ \\
\hline Cykl & 0,26 & $-1,86$ & 1,87 & $-1,06$ & $-1,26$ & 2,36 & $?$ \\
\hline Symetria & tak & nie & nie & tak & nie & nie & $?$ \\
\hline Intensywność & & & & & & & \\
Faza wzrostowa & 2,18 & 1,87 & 1,16 & 1,23 & 1,24 & 1,18 & $?$ \\
\hline Faza spadkowa & 1,56 & 2,01 & 1,15 & 2,03 & 1,72 & 0,38 & $?$ \\
\hline Cykl & 2,16 & 2,28 & 1,54 & 1,69 & 1,53 & 1,07 & $?$ \\
\hline
\end{tabular}

Źródło: opracowanie własne.

Tabela 3. Porównanie morfologii cykli z teoretycznymi modelami cyklu klasycznego i współczesnego

\begin{tabular}{|c|c|c|c|c|c|c|}
\hline & Cykl 1 & Cykl 2 & Cykl 3 & Cykl 4 & Cykl 5 & Cykl 6 \\
\hline Ilość faz & 4,00 & 2,00 & 2,00 & 2,00 & 2,00 & 2,00 \\
\hline TYP CYKLU & Klasyczny & Współczesny & Współczesny & Klasyczny & Współczesny & Współczesny \\
\hline $\begin{array}{l}\text { Punkty zwrot- } \\
\text { ne } \\
\text { Górny }\end{array}$ & $\begin{array}{l}\text { Ostry } \\
\text { i wyraźny }\end{array}$ & $\begin{array}{l}\text { Ostry } \\
\text { i wyraźny }\end{array}$ & $\begin{array}{c}\text { Ostry } \\
\text { i wyraźny }\end{array}$ & $\begin{array}{c}\text { Strefa } \\
\text { zwrotna }\end{array}$ & $\begin{array}{c}\text { Strefa } \\
\text { zwrotna }\end{array}$ & $\begin{array}{c}\text { Strefa } \\
\text { zwrotna }\end{array}$ \\
\hline Dolny & $\begin{array}{c}\text { Ostry } \\
\text { i wyraźny }\end{array}$ & $\begin{array}{c}\text { Ostry } \\
\text { i wyraźny }\end{array}$ & $\begin{array}{c}\text { Ostry } \\
\text { i wyraźny }\end{array}$ & $\begin{array}{c}\text { Ostry } \\
\text { i wyraźny }\end{array}$ & $\begin{array}{c}\text { Ostry } \\
\text { i wyraźny }\end{array}$ & $\begin{array}{c}\text { Ostry } \\
\text { i wyraźny }\end{array}$ \\
\hline TYP CYKLU & Klasyczny & Klasyczny & Klasyczny & $\begin{array}{l}\text { Niejedno- } \\
\text { znaczny }\end{array}$ & $\begin{array}{l}\text { Niejedno- } \\
\text { znaczny }\end{array}$ & $\begin{array}{l}\text { Niejedno- } \\
\text { znaczny }\end{array}$ \\
\hline Długość & 2 lata & 3 lata & 3 lata & 3-4 lata & 4 lata & 3-4 lata \\
\hline TYP CYKLU & Współczesny & Współczesny & Współczesny & Współczesny & Współczesny & Współczesny \\
\hline Amplituda & Bliska zero & Malejąca & Rosnąca & Malejąca & Malejąca & Rosnąca \\
\hline TYP CYKLU & Klasyczny & $\begin{array}{l}\text { Niejedno- } \\
\text { znaczny }\end{array}$ & Współczesny & $\begin{array}{c}\text { Niejedno- } \\
\text { znaczny }\end{array}$ & $\begin{array}{c}\text { Niejedno- } \\
\text { znaczny }\end{array}$ & Współczesny \\
\hline
\end{tabular}

Źródło: opracowanie własne. 
Warto dostrzec różnice występujące w charakterystyce cykli przed i po kryzysie z 2008 roku. Największą różnicę stanowi ich amplituda, która w okresie po kryzysie finansowym jest dodatnia (dzięki ożywieniu w Cyklu 6). Cykle 5 oraz 6 są także nieco dłuższe ze szczególnym wydłużeniem faz wzrostowych i skróceniem faz spadkowych. Cykle te mają także niższą intensywność.

\section{DYSKUSJA}

W niniejszej pracy przeprowadzono analizę sześciu cykli koniunkturalnych:

Cykl 1 - pierwszy relatywnie stabilny cykl koniunkturalny Polski po przemianach ustrojowych.

Cykl 2 - cykl po tzw. kryzysie azjatyckim i rosyjskim.

Cykl 3 - zapoczątkował ożywienie po globalnym spowolnieniu związanym z kryzysem spółek internetowych.

Cykl 4 - w czasie którego nastąpił kryzys.

Cykl 5 - cykl pokryzysowy.

Cykl 6 - cykl ożywienia gospodarczego.

Żaden z cykli nie pokrywa się w pełni pod względem charakterystyki morfologicznej z charakterystyką cyklu klasycznego i współczesnego. Jedynym wyjątkiem jest długość, co wskazuje na podobieństwo do cyklu współczesnego (około 4 lat; za wyjątkiem 2-letniego Cyklu 1 spełniającego w pozostałych warunki cyklu klasycznego).

W badanym okresie większość punktów zwrotnych jest ostra i wyraźna, co pozwala na relatywnie łatwe wskazanie poszczególnych faz rozwoju gospodarki. Wszystkie dolne punkty zwrotne są bardzo dobrze identyfikowalne, co sugeruje, że po osiągnięciu minimalnego tempa rozwoju gospodarczego, gospodarka wyraźnie przechodzi w fazę ożywienia. W trzech ostatnich pełnych badanych cyklach, górne punkty zwrotne mają charakter stref zwrotnych. Utrudnia to znacznie jednoznacznie wskazanie, że $\mathrm{w}$ danym momencie gospodarka przechodzi w fazę spadkową.

Wydaje się być zasadne powtórzenie przeprowadzonej tu analizy za jakiś czas, gdy dostępne będą dane pokrywające większy interwał czasowy po 2008 roku. Równie użyteczne byłoby zbadanie innych agregatów ekonomicznych w kontekście możliwej ich zmiany, jaka nastąpiła po 2008 roku. Analogicznie warto sprawdzić jak zmieniły się, bądź nie, zbieżność i synchronizacja tych agregatów. Informacje te miałyby wysoką wartość w tworzeniu projekcji i zrozumienia cyklicznych procesów mających miejsce w gospodarce. 


\section{PODSUMOWANIE}

W niniejszej pracy przeprowadzona została analiza cykli koniunkturalnych w Polsce w latach 1996-2017 w celu sprawdzenia, czy cykliczność polskiej gospodarki zmieniła się w stosunku do swojego kształtu sprzed kryzysu finansowego 2007-2008 roku. Dodatkowo sprawdzone zostało, czy cechy morfologiczne cykli odpowiadają modelom cyklu klasycznego bądź współczesnego.

Wyniki jasno wskazują, że w badanym okresie gospodarka Polski nie znalazła się w recesji, lecz jej wzrost jest znacznie mniej dynamiczny niż przed kryzysem. Ponieważ prawie wszystkie badane cykle trwały około 3-4 lata, a ich charakterystyka morfologiczna uległa przemianom i częściowo spełniona jest charakterystyka cyklu współczesnego, należy oczekiwać, że kolejne cykle w coraz większym stopniu będą pokrywały się z charakterystyką cyklu współczesnego.

Rekomendowane jest przeprowadzenie podobnych badań dla dłuższego okresu. Warte analizy jest również to, czy/jak zmieniły się inne agregaty ekonomiczne przed i po kryzysie finansowym.

\section{BIBLIOGRAFIA}

Beck K., Grodzki M., 2014, Konwergencja realna i synchronizacja cykli koniunkturalnych w Unii Europejskiej, Wydawnictwo Naukowe Scholar, Warszawa.

Barczyk R., Kowalczyk Z., 1993, Metody badania koniunktury gospodarczej, PWN, Warszawa -Poznań.

Barczyk R., 2006, Nowe oblicza cyklu koniunkturalnego, PWE, Warszawa.

Białek W., 2008, Wyktady na temat cyklu koniunkturalnego, „Gazeta Giełdy Parkiet”, Warszawa.

Friedman M., Schwarz A. J, 1963, Money and Business Cycles, „Review of Economics and Statistics", vol. 45 , no. 1

Górski J., Sierpiński W., 1979, Historia powszechnej myśli ekonomicznej (1870-1950), PWN, Warszawa.

Jakimowicz A., 2005, Od Keynesa do teorii chaosu, PWN, Warszawa.

Jędruchniewicz A., 2012, Cykl koniunkturalny w teorii szkoły austriackiej, Studia i Prace Kolegium Zarządzania i Finansów Szkoły Głównej Handlowej w Warszawie, Dom Wydawniczy Elipsa, Warszawa.

Hodrick, R.J., Prescott, E.C.,1981, Post-War U.S. Business Cycles: An Empirical Investigation, „Discussion Papers” 451, Northwestern University, Center for Mathematical Studies in Economics and Management Science.

Kalecki M., 1979, Parę uwag o teorii Keynesa, Dzieła: Kapitalizm, Koniunktura i zatrudnienie, PWE, Warszawa.

Kotler P., Caslione J.A., 2009, Chaos, zarzadzanie i marketing $w$ erze turbulencji, MT Biznes, Warszawa.

Marczak K., Piech K., 2008, Cykle koniunkturalne: ujęcie historyczne i przegląd głównych teorii, Uniwersytet Warszawski, SGH w Warszawie, Warszawa. 
Massmann M., Mitchell J., Weale M., 2003, Business Cycle and Turning points: A Survey of Statistical Techniques, „National Institute Review”, vol. 183.

Mintz I., 1972, Dating American Growth Cycle in Business Cycle Today, NBER, New York.

Piech K., 2003, Międzynarodowa synchronizacja cyklu koniunkturalnego Polski, [w:] K. Piech, S. Pangsy-Kania, Diagnozowanie koniunktury gospodarczej w Polsce, Elipsa, Warszawa.

Rekowski M., 1997, Koniunktura gospodarcza Polski, Akademia, Poznań.

Smithies A., 1966, Economic Fluctuations and Growth, Readings in Business Cycle, London.

Skrzypczyńska M., 2012, Cykl koniunkturalny w Polsce - analiza sektorowa, Bank i Kredyt, Warszawa

OECD, 2017, Quarterly GDP (indicator). doi: 10.1787/b86d1fc8-en [dostęp: 05.10.2017].

\title{
ANALYSIS OF THE ECONOMIC CYCLES OF POLAND IN YEARS 1996-2017
}

\begin{abstract}
Economic fluctuations have always fascinated researches regardless of the approach the took to explain them. It is the human nature to seek for patterns in various areas, economy being one of them. For this the attempt was taken to investigate the impact of the 2008 financial crisis on the economic cycle of Poland. This paper aims at answering whether the morphology before and after the crisis changed and whether they follow theoretical model of classic/modern cycles.

The research results clearly show that the pace of growth of the Polish economy has been lower after the crisis. However, Polish economy never faced recession. Because almost all cycles lasted approximately 3.5-4 years, while their morphology was subjected to changes, they can be partly classified as modern cycles. It can be also expected that morphological characteristics of future cycle will be more and more similar to modern ones.

The added value of this research is that it clearly shows that the morphological characteristics of the economic cycles in Poland did change in terms of their amplitude in the period analyzed. What is more similar approach can be taken to investigate other economic aggregates. The results might be useful to those in whose interest is future economic performance of Poland.
\end{abstract}

Keywords: economic cycle, cycles morphology, financial crisis. 